\title{
Crops and garden products near Olkiluoto repository site
}

\author{
J. Helin ${ }^{1}$, A.T.K. Ikonen ${ }^{1}$ and T. Salo ${ }^{2}$ \\ ${ }^{1}$ Posiva Oy, Olkiluoto, 27160 Eurajoki, Finland \\ ${ }^{2}$ MTT Agrifood Research Finland, 31600 Jokioinen, Finland
}

\begin{abstract}
In Finland, Olkiluoto Island on the western coast has been selected as a repository site for spent nuclear fuel disposal. With approaching licensing steps, the biosphere assessment demonstrating the longterm safety of the repository is developed into more and more site specific. As the literature data on siterelevant crops and garden products on site-relevant soils are sparse or in some cases lacking for the elements of a high relevance to the biosphere assessment of the Olkiluoto spent fuel repository, crops and garden products were collected from farms nearby the site. The samples were then analysed for stable elements for initial contribution to the site-specific database in respect of these edibles.
\end{abstract}

\section{INTRODUCTION}

In Finland, Olkiluoto Island on the western coast has been selected as a repository site for spent nuclear fuel disposal. With approaching licensing steps (application for nuclear construction licence in 2012), the biosphere assessment demonstrating the long-term safety of the repository is developed into more and more site specific. In the case of the Olkiluoto spent nuclear fuel repository, the nuclides contributing most to the doses of the most exposed persons, and of the other public, were in the recent assessment [1] I-129 and Cl-36, with C-14 having a high contribution in some release scenarios. Other elements (corresponding to the released nuclides) of high relevance include $\mathrm{Se}, \mathrm{Mo}, \mathrm{Ni}, \mathrm{Nb}$ and $\mathrm{Cs}$, and possibly Ag.

Even though there are relatively much data on the agricultural ecosystem, e.g. the number of data underlying of the recent IAEA handbook values [2] to soil-to-plant transfer factors to the different crop types is as low as none for I, 6-14 for $\mathrm{Cl}$, none for Se, 1-3 for Mo, 27-44 for Ni, and 1-2 for Nb. Even in the case of the well-studied Cs the respective number of data is not higher than 4-470, in principle covering the variability of conditions within temperate climate domain (here as contrast to tropical and arctic climates, but normally excluding also e.g. the boreal zone where the Olkiluoto repository site is located). The number of data divided to combinations of crop type and soil type would be even less, and contribution from soil-to-fruit data in the case of some elements does not help much either; it is evident that also for crops a site-specific database is needed not only to ensure the appropriateness of the literature data applied but also to fill the data gaps - work that should have been initiated long ago but was not that apparent before entering to the real site-specific stage along with the nearing onset of construction of the repository.

To initialise the collection of the site-specific data on soil-to-crop transfer, and other parameters relevant to the radionuclide transfer and dose assessments, common crops and garden products were sampled from two farms nearby the repository site in the autumn of 2010 . The farms were selected on the basis of familiarity and experience of good co-operation, and the different crops were then chosen based on the availability at the farm. 


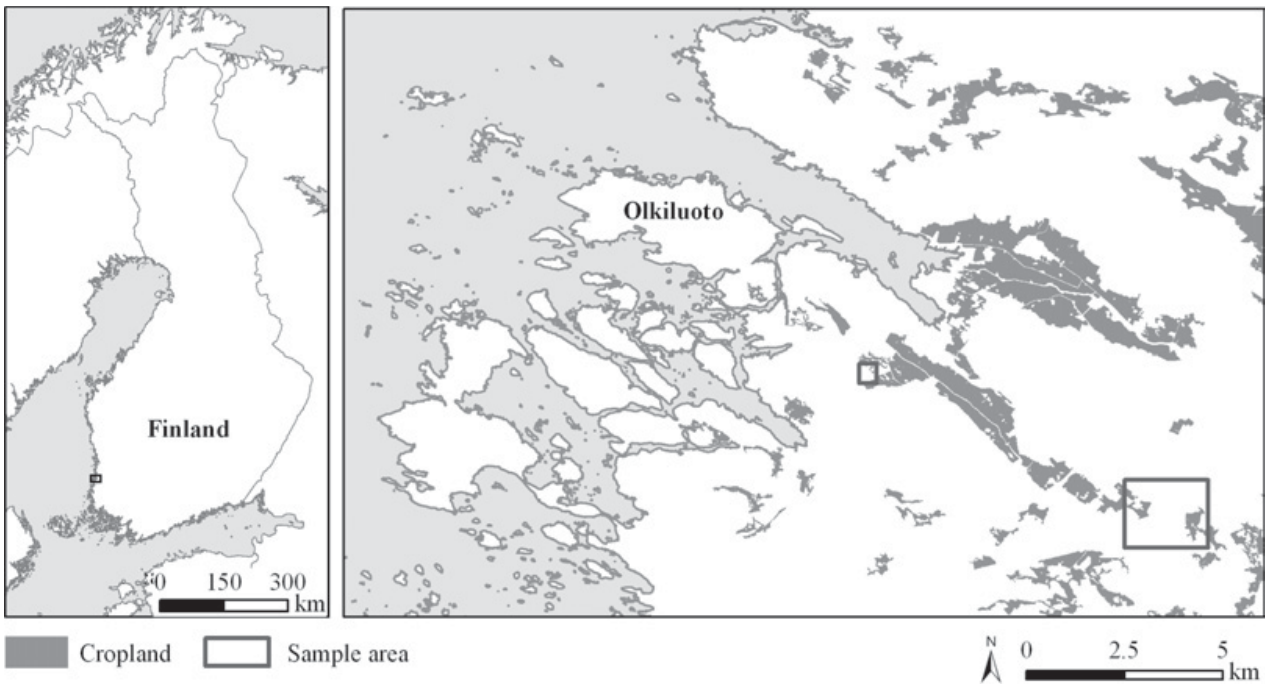

Figure 1. Sampling areas of the crop and garden products in relation to the Olkiluoto site. Croplands in the area are shown with the grey shading. Background map from the topographic database by the National Land Survey of Finland, permission no. 41/MYY/11; map layout by Jani Helin, Posiva Oy.

\section{MATERIAL AND METHODS}

\subsection{Sampling sites}

The farms where the crops and garden products were sampled both locate close to the Olkiluoto repository site in the municipality of Eurajoki, south-western Finland. Barley, carrot and zucchini were sampled in 1 September 2010 (zucchini already in 2008) from a farm $15 \mathrm{~km}$ southeast of the Olkiluoto site. The farm had its individual fields scattered within a few kilometres. From a smaller commercial garden, $6 \mathrm{~km}$ southeast from Olkiluoto, lettuce and berries of red and black currant were sampled in 17 August 2010.

\subsection{Sampling}

In the sampling of barley and carrot, all plant material from three quadrats of $0.5 \times 0.5 \mathrm{~m}^{2}$ was carefully collected. In the laboratory, the samples were separated into different plant fractions that were weighed for their contribution to the biomass. The sampling locations were chosen subjectively to represent the average growth conditions of the field plot. Two individuals of zucchini (500 and $550 \mathrm{~g}_{\mathrm{fw}}$ ) were randomly picked from a zucchini field. In the case of lettuce, three individual plants were collected from two locations within the field. Berries of red and black currant were collected each from a single bush. All the plant samples were collected to clean plastic bags, and the non-edible parts of the samples were removed in the laboratory, and the samples were rinsed as in household use but with distilled water to remove excess amount of soil. Also the above-ground parts of the plant samples were rinsed with distilled water to remove the possible atmospheric deposition component.

From each sampling location (quadrat, bush, or zucchini or lettuce sampling point), soil was sampled from the top $30 \mathrm{~cm}$ layer by first digging a hole of sufficient depth and then scraping sample material with a plastic shovel from bottom up to a clean plastic box so that the sample represents evenly the whole $30-\mathrm{cm}$ soil column.

The carrot field is former mire that had been drained into a field; the bulk density of soil was $0.56 \mathrm{~g}_{\mathrm{dw}} / \mathrm{m}^{3}(0-30 \mathrm{~cm})$ based on a single density sample taken to a plastic tube of known volume and 
dried to the constant weight at $105^{\circ} \mathrm{C}$. Following the common practise, three carrot rows were sown on a width of the tractor $(1.8 \mathrm{~m})$ with $40 \mathrm{~cm}$ wide tires; a row of carrots was about $45 \mathrm{~cm}$ wide.

Within the barley plot, a part of the area had a notably dense growth of weeds, and these areas were excluded from the sampling. The height of the barley was $53 \mathrm{~cm}(\operatorname{std} 4.8 \mathrm{~cm}, \mathrm{~N} \mathrm{15})$. Based on samples taken from a single point to plastic tubes and dried in $105^{\circ} \mathrm{C}$, the bulk densities of the soil layer of top $0-30 \mathrm{~cm}$ is $1.4 \mathrm{~g}_{\mathrm{dw}} / \mathrm{m}^{3}$ with a distinctively looser top layer of $0-10 \mathrm{~cm}$ of $1.1 \mathrm{~g}_{\mathrm{dw}} / \mathrm{m}^{3}$, compared to the $1.6 \mathrm{~g}_{\mathrm{dw}} / \mathrm{m}^{3}$ at the depth of $10-30 \mathrm{~cm}$. Sandy subsoil was occasionally observed in the three soil sampling pits from a depth of approximately $25 \mathrm{~cm}$.

The red and black currant bushes (172 and $135 \mathrm{~cm}$ high and 275 and $235 \mathrm{~cm}$ wide, respectively) were in an immediate vicinity of a residential house on the commercial garden and were surrounded by lawn. There was only some litter and no humus layer under the bushes. Lettuce was growing on a clayey field plot next to a greenhouse and sampled from the crop remaining after a harvest for a previous client.

\subsection{Pre-treatment}

In the laboratory the samples were then further divided into subsamples for laboratory analyses (section 2.4) and for archive, when allowed by the sample size. Dry matter content (DM) was determined from subsamples by drying at $105^{\circ} \mathrm{C}$ for at least $48 \mathrm{~h}$. In cases of logistical delay in pre-treatment samples were stored in a fridge (only short periods) or a freezer. The prepared samples were all frozen for transport to the analytical laboratory or for archive.

\subsection{Chemical analyses}

All samples were analysed in the commercial laboratory of ALS Scandinavia AB. Element composition of the plant samples was determined with a total elemental analysis (ICP-SFMS) after drying at $50^{\circ} \mathrm{C}$ and digestion with $\mathrm{HNO}_{3} / \mathrm{HF}$ (trace). The soil samples were analysed for "bioavailable" element concentrations after an $\mathrm{NH}_{4} \mathrm{Ac}$ extraction: $1 \mathrm{M} \mathrm{NH} 4 \mathrm{Ac}$ extraction (ratio $1: 10$ ) was done at $\mathrm{pH} 4.5$ with ICP-MS/ICP-OES techniques. For analyses, $3 \mathrm{~g}$ of dried and homogenised soil was weighed. After dilution, the leachates were analyzed for 69 elements by ICP-SFMS with methane addition to achieve the best possible limits of quantification (LOQ) for some elements. To obtain total element concentrations, another aliquot of each soil sample was analysed using a $\mathrm{LiBO}_{2}$ fusion (for $\mathrm{Mo}, \mathrm{Nb}, \mathrm{Ni}$, $\mathrm{Sr}$ of the elements reported here) and $\mathrm{HNO}_{3} / \mathrm{HF}$ (trace) digestion preceding ICP-AES and ICP-SFMS with methane addition to achieve the best possible LOQs for Ag.

\subsection{Derivation of concentration ratios}

Concentration ratio (CR) approach is a simple and the most widely used method of quantifying radionuclide transfer in the environment, especially in relation to human radiological protection [3]. The approach involves the assumption that an organism is in biogeochemical equilibrium with its surroundings [3]. For a CR, the concentration in part of the organism is divided by the concentration in its surrounding medium, i.e. here by the concentration in the soil sampled at a depth of 0-30 cm. The concentration ratios are calculated on the basis of both the "bioavailable" $\left(\mathrm{NH}_{4} \mathrm{Ac}\right)$ concentrations and the total element $\left(\mathrm{LiBO}_{2} / \mathrm{HNO}_{3} / \mathrm{HF}\right)$ concentrations; the latter is frequently used but the former would be more accurate in modelling the plant uptake given the growth conditions as long as the other parameters like the solid/liquid distribution coefficient are defined consistently.

\section{RESULTS AND DISCUSSION}

As barley and carrot were sampled using quadrats, their biomasses on an area basis are possible to determine. The above-ground vegetation biomass in the barley field was $410 \mathrm{~g}_{\mathrm{dw}} / \mathrm{m}^{2}$ (average of three 
Table 1. Dry matter contents $\left(\mathrm{kg}_{\mathrm{dw}} / \mathrm{kg}_{\mathrm{fw}}\right)$ of the studied crop and garden product samples (arithmetic mean, standard error and number of samples); * denotes that the data is for the rinsed samples, ** freeze drying (the other samples were dried in $105^{\circ} \mathrm{C}$ ).

\begin{tabular}{|c|l|l|l|r|}
\hline \multirow{4}{*}{ Barley } & & \multicolumn{1}{|c|}{ AM } & \multicolumn{1}{|c|}{ SE } & N \\
\hline & whole plant & 0.41 & 0.02 & 10 \\
\cline { 2 - 5 } & ears & 0.48 & 0.008 & 2 \\
\cline { 2 - 5 } & stems & 0.23 & 0.02 & 3 \\
\cline { 2 - 5 } & other parts & 0.23 & 0.002 & 2 \\
\hline \multirow{3}{*}{ Carrot } & whole plant & 0.123 & 0.010 & 11 \\
\cline { 2 - 5 } & haulms & 0.143 & 0.010 & 11 \\
\cline { 2 - 5 } & roots & 0.115 & 0.009 & 11 \\
\hline Lettuce & leaves & 0.05 & 0.01 & 2 \\
\hline Red currant & berries & 0.26 & & 1 \\
\hline Black currant** & berries* & 0.20 & & 1 \\
\hline Zucchini & edible part* & 0.045 & 0.002 & 2 \\
\hline
\end{tabular}

quadrats of $0.5 \times 0.5 \mathrm{~m}^{2}$ ) of which the ears constituted $62 \%$ and barley stems $29 \%$, on dry weight basis, rest being barley leaves and weeds. Correspondingly, there was $1170 \mathrm{~g}_{\mathrm{dw}} / \mathrm{m}^{2}$ of biomass in the carrot field, of which $41 \%$ was carrot haulms and rest the carrot roots.

From separate samples of individual plants collected next to the biomass sampling quadrats, the mass of a carrot individual was $36 \pm 7 \mathrm{~g}_{\mathrm{dw}}$ (arithmetic mean \pm standard error, $\mathrm{N}=10$ ), of which the haulms were $29 \pm 3 \%$ (10); this gives an estimate of 47 carrots $/ \mathrm{m}^{2}$. The mean length of the carrot root was $20.8 \pm 1.2 \mathrm{~cm}$ (10) and the diameter $4.5 \pm 0.1$ (20). The haulms were $64.0 \pm 1.3 \mathrm{~cm}$ (10) long. From the corresponding samples of individuals of barley, a length of $57.4 \pm 1.5 \mathrm{~cm}(24)$ and a mass of $1.44 \pm 0.11 \mathrm{~g}_{\mathrm{dw}}$ (10) was determined, giving an estimate of 260 individuals $/ \mathrm{m}^{2}$. From the lettuce samples, a height of $49 \pm 4 \mathrm{~cm}$ (8) and a width of $35 \pm 2$ (16) were measured. The edible part of the plants weighed $3.2 \pm 0.7 \mathrm{~g}_{\mathrm{dw}}(6)$. Corresponding dry matter concentrations are presented in Table 1.

The concentrations in the edible plant parts (Table 2) were rather similar across the plants: Generally the concentrations of an element are roughly the same in all species, with the exception of the lettuce showing 1-2 orders of magnitude higher concentrations for most of the studied elements than the other plants. Also the carrot is very high in chlorine and nickel compared to the others. Strontium concentrations in the carrot, the lettuce and the zucchini are an order of magnitude higher than in the barley ears or in the currant berries. The difference in growth sites could have an effect but the concentrations in the soils are rather similar (see below).

As expected, both the "bioavailable" (Table 3) and the total element (Table 4) concentrations are roughly on the same level across the soil samples. Even between the two farms nearly 10 kilometres apart the concentrations in soil are about the same, except for $\mathrm{Nb}$ for which there is a difference of one order of magnitude between the farms. Table 3 includes also the "bioavailable" fraction of the total element concentrations across all soil samples. $\mathrm{Cs}$ and $\mathrm{Nb}$, and also to some extent $\mathrm{Mo}$, I and $\mathrm{Ni}$, are relatively strongly sorbed, whereas from $\mathrm{Cl} 33 \%$ and from $\mathrm{Sr} 30 \%$ is in the "bioavailable" fraction. $\mathrm{Ag}$ appears to be more fixed in the soil on the lettuce and black currant plots than the soil samples from the other farm, with the red currant plot in the middle in concentrations. The carrot plot which is a drained mire (high in organic matter) shows a higher fixed fraction of $\mathrm{Ag}, \mathrm{Cl}$ and $\mathrm{Se}$.

The concentration ratios (CRs) are presented here both in respect to the "bioavailable" concentrations in the soil (Table 5) and, more traditionally, based on the total element concentrations (Table 6). Following from the small variability in the "bioavailable"-to-total concentration fractions in the soils (Table 3), also the different CRs have a similar pattern between each other across the elements 
Table 2. Element concentrations $\left(\mathrm{mg} / \mathrm{kg}_{\mathrm{dw}}\right)$ in the edible parts of the sampled plants (zucchini: flesh, skin and seeds). All samples except zucchini have been rinsed with distilled water to remove the potential atmospheric deposition component and soil excess to common household use. For the lettuce and the zucchini the arithmetic mean \pm standard error are given for the two samples analysed. In the carrot, the I and Se concentrations were below the limit of quantification.

\begin{tabular}{|c|c|c|c|c|c|c|c|c|c|}
\hline $\begin{array}{c}\text { Plant } \\
\text { samples }\end{array}$ & $\mathrm{Ag}$ & $\mathrm{Cl}$ & $\mathrm{Cs}$ & $\mathrm{I}$ & $\mathrm{Mo}$ & $\mathrm{Nb}$ & $\mathrm{Ni}$ & $\mathrm{Se}$ & $\mathrm{Sr}$ \\
\hline $\begin{array}{c}\text { Barley } \\
\text { ears }\end{array}$ & 0.0018 & 440 & 0.0025 & 0.046 & 0.68 & 0.0016 & 0.068 & 0.18 & 2.8 \\
\hline $\begin{array}{c}\text { Carrot } \\
\text { (root) }\end{array}$ & $\mathrm{n} . \mathrm{a}$. & 11000 & 0.011 & $<0.4$ & 0.11 & $\mathrm{n} . \mathrm{a}$. & 8.0 & $<0.9$ & 20 \\
\hline $\begin{array}{c}\text { Lettuce } \\
0.00306 \\
\pm 0.00005\end{array}$ & $\begin{array}{c}9000 \\
\pm 4000\end{array}$ & $\begin{array}{c}0.11 \\
\pm 0.05\end{array}$ & $\begin{array}{c}1.4 \\
\pm 0.5\end{array}$ & $\begin{array}{c}7.3 \\
\pm 1.5\end{array}$ & $\begin{array}{c}0.069 \\
\pm 0.010\end{array}$ & $\begin{array}{c}0.513 \\
\pm 0.002\end{array}$ & $\begin{array}{c}0.072 \\
\pm 0.012\end{array}$ & $\begin{array}{c}29.4 \\
\pm 4.4\end{array}$ \\
\hline $\begin{array}{c}\text { Red curr. } \\
\text { berries }\end{array}$ & 0.0024 & 360 & 0.0027 & 0.052 & 0.36 & 0.0013 & 0.7 & 0.021 & 2.8 \\
\hline $\begin{array}{c}\text { Black } \\
\text { curr. berr. }\end{array}$ & 0.00056 & 300 & 0.0029 & 0.38 & 0.77 & 0.00056 & 0.33 & 0.053 & 4.4 \\
\hline $\begin{array}{c}\text { Zucchini } \\
0.0138\end{array}$ & $\begin{array}{c}3060 \\
\pm 40\end{array}$ & $\begin{array}{c}0.009 \\
\pm 0.002\end{array}$ & $\begin{array}{c}0.17 \\
\pm 0.05\end{array}$ & $\begin{array}{c}1.4 \\
\pm 0.3\end{array}$ & $\begin{array}{c}0.008 \\
\pm 0.002\end{array}$ & $\begin{array}{c}0.93 \\
\pm 0.08\end{array}$ & $\begin{array}{c}0.129 \\
\pm 0.01\end{array}$ & $\begin{array}{c}22 \\
\pm 2\end{array}$ \\
\hline
\end{tabular}

Table 3. "Bioavailable" element concentrations $\left(\mathrm{mg} / \mathrm{kg}_{\mathrm{dw}}\right)$ in the soil samples. For the lettuce the arithmetic mean \pm standard error are given for the two samples analysed. Also the fraction of the "bioavailable" concentrations of the total element concentrations across all sampling plots are given (mean \pm s.e.).

\begin{tabular}{|c|c|c|c|c|c|c|c|c|c|}
\hline Soil, $\mathrm{NH}_{4} \mathrm{Ac}$ & $\mathrm{Ag}$ & $\mathrm{Cl}$ & $\mathrm{Cs}$ & I & Mo & $\mathrm{Nb}$ & $\mathrm{Ni}$ & $\mathrm{Se}$ & $\mathrm{Sr}$ \\
\hline Barley plot & 0.0047 & 23 & 0.013 & 0.31 & 0.020 & 0.042 & 0.39 & n.a. & 5.7 \\
\hline Carrot plot & 0.0029 & 13 & 0.007 & 0.32 & 0.025 & 0.014 & 1.1 & 0.052 & 37 \\
\hline Lettuce plots & $\begin{array}{c}0.0038 \\
\pm 0.0002\end{array}$ & $\begin{array}{c}6 \\
\pm 2\end{array}$ & $\begin{array}{c}0.0106 \\
\pm 0.0006\end{array}$ & $\begin{array}{c}0.2255 \\
\pm 0.0005\end{array}$ & $\begin{array}{c}0.027 \\
\pm 0.002\end{array}$ & $\begin{array}{c}0.00136 \\
\pm 0.00007\end{array}$ & $\begin{array}{c}0.6 \\
\pm 0.02\end{array}$ & n.a. & $\begin{array}{c}8.1 \\
\pm 0.6\end{array}$ \\
\hline Red curr. plot & 0.0052 & 2.6 & 0.0089 & 0.14 & 0.015 & 0.0021 & 0.75 & 0.026 & 2.4 \\
\hline Black curr. plot & 0.0012 & 10 & 0.010 & 0.13 & 0.012 & 0.0015 & 0.76 & n.a. & 11 \\
\hline Zucchini plot & 0.011 & n.a. & 0.013 & 0.24 & 0.017 & 0.0091 & 0.54 & 0.054 & 12 \\
\hline $\begin{array}{l}\text { "Bioavailable", } \\
\% \text { of total conc. }\end{array}$ & $\begin{array}{l}13 \\
\pm 2\end{array}$ & $\begin{array}{l}33 \\
\pm 2\end{array}$ & $\begin{array}{c}0.70 \\
\pm 0.02\end{array}$ & $\begin{array}{c}6.6 \\
\pm 0.5\end{array}$ & $\begin{array}{c}1.31 \\
\pm 0.06\end{array}$ & $\begin{array}{c}0.56 \\
\pm 0.11\end{array}$ & $\begin{array}{c}6.26 \\
\pm 0.12\end{array}$ & $\begin{array}{r}13 \\
\pm 2\end{array}$ & $\begin{array}{l}29.7 \\
\pm 1.5\end{array}$ \\
\hline
\end{tabular}

Table 4. Total element concentrations $\left(\mathrm{mg} / \mathrm{kg}_{\mathrm{dw}}\right)$ in the soil samples. For the lettuce the arithmetic mean \pm standard error are given for the two samples analysed.

\begin{tabular}{|c|c|c|c|c|c|c|c|c|c|}
\hline Soil, total conc. & $\mathrm{Ag}$ & $\mathrm{Cl}$ & $\mathrm{Cs}$ & $\mathrm{I}$ & $\mathrm{Mo}$ & $\mathrm{Nb}$ & $\mathrm{Ni}$ & $\mathrm{Se}$ & $\mathrm{Sr}$ \\
\hline Barley plot & 0.017 & 62 & 1.5 & 2.5 & 1.1 & 1.9 & 7.4 & 0.52 & 21 \\
\hline Carrot plot & 0.060 & 92 & 1.4 & 11 & 2.5 & 2.3 & 17 & 0.94 & 80 \\
\hline Lettuce plots & 0.08 & 18 & 1.5 & 4.205 & 2.1 & 1.55 & 10.6 & 0.23 & 29 \\
& \pm 0.04 & \pm 9 & \pm 0.07 & \pm 0.015 & \pm 0.2 & \pm 0.09 & \pm 0.6 & \pm 0.06 & \pm 2 \\
\hline Red curr. plot & 0.035 & 8.6 & 1.4 & 2.0 & 1.3 & 1.4 & 9.9 & 0.17 & 19 \\
\hline Black curr. plot & 0.041 & 28 & 1.5 & 3.1 & 1.7 & 1.3 & 11 & 0.15 & 36 \\
\hline Zucchini plot & 0.037 & n.a. & 1.5 & 2.8 & 0.89 & 1.3 & 8.3 & 0.28 & 34 \\
\hline
\end{tabular}

and the plants. Generally, CRs to the lettuce are in their own class (one or two orders of magnitude higher) with the exceptions of $\mathrm{Ag}, \mathrm{Ni}$ and Se for which the lettuce CRs present the average level across the plant species. Also, CRs to the carrot are an order of magnitude higher for Ni than in case of the other plants, similarly to the case of the black currant for I, the carrot for $\mathrm{Cl}$ and the zucchini for Mo, 
Table 5. "Bioavailable" concentration ratios $\left(\left(\mathrm{mg} / \mathrm{kg}_{\mathrm{dw}}\right) /\left(\mathrm{mg} / \mathrm{kg}_{\mathrm{dw}}\right)\right)$ to the edible parts of the plants based on the $\mathrm{NH}_{4} \mathrm{Ac}$-extracted concentrations in the soil. For the lettuce the arithmetic mean \pm standard error are given for the two paired samples analysed. For the carrot, concentrations in the plant part were below the limit of quantification, used here as such for an upper estimate of the CR.

\begin{tabular}{|c|c|c|c|c|c|c|c|c|c|}
\hline CR, bioav. & $\mathrm{Ag}$ & $\mathrm{Cl}$ & Cs & $\mathrm{I}$ & Mo & $\mathrm{Nb}$ & $\mathrm{Ni}$ & $\mathrm{Se}$ & $\mathrm{Sr}$ \\
\hline Barley ears & 0.39 & 19 & 0.19 & 0.15 & 34 & 0.037 & 0.18 & n.a. & 0.49 \\
\hline Carrot (root) & n.a. & 840 & 1.6 & $<1.2$ & 4.4 & n.a. & 7.5 & $<17$ & 0.55 \\
\hline Lettuce & $\begin{array}{c}0.82 \\
\pm 0.07\end{array}$ & $\begin{array}{r}1400 \\
\pm 300\end{array}$ & $\begin{array}{l}10 \\
\pm 4\end{array}$ & $\begin{array}{c}6 \\
\pm 2\end{array}$ & $\begin{array}{l}270 \\
\pm 30\end{array}$ & $\begin{array}{l}51 \\
\pm 5\end{array}$ & $\begin{array}{c}0.86 \\
\pm 0.02\end{array}$ & n.a. & $\begin{array}{c}3.7 \\
\pm 0.8\end{array}$ \\
\hline Red curr. berries & 0.46 & 140 & 0.30 & 0.36 & 24 & 0.64 & 0.93 & 0.81 & 1.2 \\
\hline Black curr. berr. & 0.48 & 29 & 0.28 & 3.0 & 67 & 0.37 & 0.43 & n.a. & 0.4 \\
\hline Zucchini & 1.3 & n.a. & 0.69 & 0.68 & 83 & 0.92 & 1.7 & 2.4 & 1.9 \\
\hline
\end{tabular}

Table 6. Concentration ratios $\left(\left(\mathrm{mg} / \mathrm{kg}_{\mathrm{dw}}\right) /\left(\mathrm{mg} / \mathrm{kg}_{\mathrm{dw}}\right)\right)$ to the edible parts of the plants based on the total element concentrations in the soil. For the lettuce the arithmetic mean \pm standard error are given for the two samples analysed. For the carrot, concentrations in the plant part were below the limit of quantification, used here as such for an upper estimate of the CR.

\begin{tabular}{|c|c|c|c|c|c|c|c|c|c|}
\hline CR, total conc. & $\mathrm{Ag}$ & $\mathrm{Cl}$ & $\mathrm{Cs}$ & $\mathrm{I}$ & $\mathrm{Mo}$ & $\mathrm{Nb}$ & $\mathrm{Ni}$ & $\mathrm{Se}$ & $\mathrm{Sr}$ \\
\hline Barley ears & 0.11 & 7.2 & 0.0016 & 0.018 & 0.63 & 0.00082 & 0.009 & 0.35 & 0.13 \\
\hline Carrot (root) & n.a. & 120 & 0.008 & $<0.037$ & 0.044 & n.a. & 0.46 & $<0.96$ & 0.26 \\
\hline Lettuce & 0.05 & 510 & 0.07 & 0.32 & 3.4 & 0.045 & 0.049 & 0.32 & 1.02 \\
\pm 0.02 & \pm 20 & \pm 0.03 & \pm 0.12 & \pm 0.4 & \pm 0.009 & \pm 0.003 & \pm 0.04 & \pm 0.10 \\
\hline $\begin{array}{c}\text { Red curr. } \\
\text { berries }\end{array}$ & 0.07 & 42 & 0.0019 & 0.026 & 0.28 & 0.00091 & 0.071 & 0.12 & 0.15 \\
\hline $\begin{array}{c}\text { Black curr. } \\
\text { berr. }\end{array}$ & 0.014 & 11 & 0.0019 & 0.12 & 0.46 & 0.00043 & 0.029 & 0.36 & 0.12 \\
\hline Zucchini & 0.37 & n.a. & 0.0058 & 0.059 & 1.6 & 0.0064 & 0.11 & 0.47 & 0.66 \\
\hline
\end{tabular}

$\mathrm{Nb}$ and $\mathrm{Ni}$. On the other hand, Mo seems to have a lower $\mathrm{CR}$ to the carrot than the other plants. $\mathrm{Cl}$ and $\mathrm{Nb}$ to the barley ears and $\mathrm{Cl}$ to the black currant show similar tendency even though not so clearly.

By comparing the CRs, calculated from the total element concentrations in the soil, to recent compendium values $[2,4]$, it can be observed that in most cases our concentration ratios are within an order of magnitude of them. The nearly two order of magnitude difference to the IAEA values [2] in case of $\mathrm{Sr}$ to the barley ears may be due to the IAEA value to grains of several cereals; on the other hand, our value here is close to that of the Canadian study [4]. The rather large value, by a factor of 280, compared to the IAEA data on Ag to the lettuce leaves may be similarly arising from the inclusion of all leafy vegetables to the IAEA value (derived from only five data points). Similarly, our CR for Ag to the zucchini is 580-fold to the IAEA value for fruits, heads, berries and buds of any non-leafy vegetables. In both these cases, our values agree well with the Canadian data. Our values are somewhat different to both the IAEA and the Canadian data only regarding chlorine to the carrot and to the lettuce, but this can be again attributed to the larger representativeness of the crop type in the literature. Also our value for $\mathrm{Ni}$ to the carrot is about 30-fold to the Canadian one, but the latter includes also beetroots - and generally more samples. The 30 -fold difference with I to the black currant compared to the Canadian value to berries is reasonable as the latter is a CR to blueberry, but it is rather surprising that the other CRs of $\mathrm{Cs}, \mathrm{Mo}, \mathrm{Nb}, \mathrm{Ni}$ and $\mathrm{Sr}$ to both red and black currant and the $\mathrm{CR}$ of I to the red currant are as close to the blueberry data as they are (ours being 0.1 - to 7 -fold depending on the element). 


\section{CONCLUSIONS}

Crops and garden products were sampled from a region close to the Olkiluoto spent nuclear fuel repository site for data on elements most relevant to the repository safety case: $\mathrm{I}, \mathrm{Cl}, \mathrm{Se}, \mathrm{Mo}, \mathrm{Ni}$, $\mathrm{Nb}, \mathrm{Cs}$ and $\mathrm{Ag}$. The derived concentration ratios correspond generally to those presented in recent compendia, with few reasonable exceptions. The results will contribute to the site-specific data basis for the biosphere assessments of the spent fuel repository.

\section{Acknowledgments}

The authors thank the farmers from whom the farm products were obtained and who kindly assisted in the sampling.

\section{References}

[1] Hjerpe T. Ikonen A.T.K. \& Broed R., POSIVA Report 2010-03 (2010) 1-185.

[2] IAEA, Technical Report Series 472 (2010) 1-194.

[3] Hosseini, A. Thørring, H., Brown, J.E., Saxén, R., Ilus, E., J. Environ. Radioact. 99 (2008) 14081429.

[4] Sheppard, S.C., Long, J., Sanipelli, B., NWMO TR 2009-35 (2009) 1-63. 